This is a report from the National Bureau of Economic Research

Title: Mobile money and healthcare use: evidence from East Africa Authors: Ahmed, Haseeb; Cowan, Benjamin

Publication year: 2019

Series: NBER working papers

Number in series: 25669

Publisher: National Bureau of Economic Research

This publication is available in SLU publication database at http://epsilon.slu.se/ 


\title{
MOBILE MONEY AND HEALTHCARE USE: EVIDENCE FROM EAST AFRICA
}

\author{
Haseeb Ahmed \\ Department of Economics \\ Information Technology University, Lahore \\ and Sveriges Lantbruksuniversitet (SLU), Sweden \\ 55244, VHC Building, Ulls Väg 26, Uppsala \\ haseeb.ahmed@slu.se \\ Benjamin Cowan \\ School of Economic Sciences \\ Washington State University \\ and NBER \\ 203F, Hulbert Hall, Pullman WA. \\ ben.cowan@wsu.edu
}

\begin{abstract}
This paper uses a difference-in-difference framework to estimate the effects of mobile money transfer technology (MMT) on healthcare usage in the face of negative health shocks. We use survey data from 2013-16 with quarterly observations on about 1,600 households of 10 villages in the Kisumu region of Western Kenya. We find evidence that MMT, likely through greater ease of informal borrowing, helps households increase utilization of formal healthcare services in terms of visits to a clinic, consultation and medication expenditures in comparison with the nonusers of this technology.
\end{abstract}




\section{Introduction}

Lack of access to financial services restricts the ability of poor households to save and invest and engage in formal insurance mechanisms (Johnson and Nino-Zarazua 2011; Dupas and Robinson 2009). Therefore, poor households often rely on informal risk sharing mechanisms during periods of distress. This informal risk sharing and insurance is generally incomplete due to information asymmetries and transaction costs (Gertler and Gruber 2002; Townsend 1995; Kochar 1995; Gertler, Levine and Moretti 2006, 2009). Mobile money transfer technology (MMT) has the potential to improve risk sharing in the presence of income shocks, as it allows its owners to store monetary value on a mobile phone. This value can be sent or received simply by text (SMS) messages, thus reducing the transaction costs associated with borrowing and lending (Jack and Suri 2014; Suri and Jack 2016; Munyegera and Matsumoto 2016; Blumenstock, Eagle and Fafchamps 2011; Riley 2018; Bharadwaj et al. 2019). ${ }^{1}$

The objective of this paper is to test the impact of MMT on risk-sharing in the face of negative health shocks. Jack and Suri (2014) use a difference-in-difference specification to examine changes in consumption in response to negative unexpected income and health shocks across MMT users and non-users. Our paper builds on this work by using the Socio-Economic Survey (SES) conducted by Kenya Medical Research Institute (KEMRI) and Centers for Disease Control (CDC) and by focusing on the impact of MMT adoption on health expenditures and healthcare use under negative health shocks. Additionally, our focus is on rural households, whereas Jack and Suri (2014) use a combined sample of urban and rural households. MMT adoption may be especially important for insurance purposes in rural areas, which often have

\footnotetext{
${ }^{1}$ To illustrate the reduction in transaction costs, Jack and Suri (2014) document that the average distance of a person-to-person remittance in Kenya is $200 \mathrm{~km}$, which costs about \$5 in travel expenses. With the help of MMT, funds can be transferred by a simple SMS, saving time and money.
} 
higher poverty rates and less access to formal financial services in developing countries. At the same time, inadequate MMT agent services in rural areas can discourage households from adopting this technology (Morawczynski and Pickens 2009).

Effective and accessible healthcare has been recognized as pivotal in improving living standards and reducing poverty. Credit constraints and the high cost of health services contribute to keeping more than a billion people in low and middle income countries from using recommended healthcare (Harris et al. 2011). Given that borrowing within informal networks is the predominant insurance mechanism among the poorer, unbanked households of the developing world (Fafchamps and Lund 2003; Gertler, Levine and Moretti 2009; Mobarak and Rosenzweig 2013), MMT can help households overcome these credit constraints by making it easier to borrow money from relatives and friends. Healthcare use is particularly important in our setting as febrile illnesses, diarrheal illnesses and respiratory disorders are endemic in the region and make up $40.2 \%, 5 \%$ and $54.4 \%$ of the health shocks, respectively (Thumbi et al. 2015).

Jack and Suri (2014) show that users of MMT can better smooth consumption for total, food and other non-health expenditure categories under idiosyncratic negative shocks, while Riley (2018) shows the potential for consumption smoothing under village-level shocks. In contrast, our results indicate that the risk sharing effects are concentrated on health expenditures and healthcare use in the presence of a negative health shock, but other categories of expenditures (such as those examined by Jack and Suri (2014)) are not affected. By using a different dataset and focusing specifically on healthcare use, this paper contributes to the literature by showing that users of MMT, presumably through increased informal borrowing, use more healthcare services compared to non-users in the presence of health shocks. This suggests that MMT can be an effective tool for overcoming short-run credit constraints and financing of unplanned and 
sudden expenditures imposed by illness. This access to credit in the time of need, usually through informal networks (Fafchamps and Lund 2003; Fafchamps and Gubert 2007), may lead to timely diagnosis, prevention and treatment of disease, and thus have important repercussions for household health.

A challenge for our identification strategy is that MMT adoption is endogenous. MMT has been associated with an increase in the privacy of transactions, thereby providing more freedom to women in choosing where to spend their money and also improving the gender parity situation within households (Aker et al. 2011; Jackiela and Ozier 2015). Users of MMT have higher offfarm employment and farm profits, spend cash on more diverse items, sell fewer non-durable assets and cultivate more diverse crops (Aker et al. 2011; Suri and Jack 2016; Kikulwe et al. 2014).

The validity of our identification strategy rests on the assumption that health shocks are exogenous. We find that health shocks are uncorrelated with observables, suggesting that these shocks are exogenous and equally affect users and non-users of MMT. If this is the case, we will obtain unbiased estimates of the effect of MMT on consumption smoothing as long as unobserved differences between MMT user and non-users do not vary by health shock status. Like Jack and Suri (2014), we allow for all observable household characteristics to affect risk sharing by interacting them with health shocks. This allows us to control for other changes in a household's environment that may also affect a household's consumption smoothing ability.

MMT eases consumption smoothing through liquidation of savings or through increased remittances and loans. We test the impact of MMT adoption on likelihood of acquiring a loan (formally or informally) with our difference-in-difference strategy. Since families in Kenya are dispersed over large distances due to internal migration and employment opportunities (Agesa 
and Agesa 1999; Jack and Suri 2014), lowering transaction costs can have crucial effects on frequency and timeliness of needed remittances and loans. We find that MMT users are 5 percentage points more likely to acquire loans than non-users during a negative health shock, indicating that borrowing may be the main mechanism.

Lastly, we note that households in rural areas may rely on in-kind transfers for consumption smoothing during health or income shocks, especially if they do not currently have MMT. In other words, in-kind transfers may be a substitute for cash transfers (via MMT) in the absence of MMT. We examine this possibility using the quantity of maize received as a gift as the dependent variable in our difference-in-difference model. We find that the quantity of maize received as a gift increases for MMT non-users but does not increase for MMT users under a health shock. This is consistent with the substitution hypothesis. It is important to note these inkind transfers do not lead to increased formal medical care during health shocks the way MMT does. This may be a result of cash transfers via MMT being more liquid than in-kind transfers, thus making it easier to put them toward healthcare expenditures.

\section{Background and Data}

Mobile money was introduced in Africa in 2007 and its adoption grew steadily over time. MMT services are provided by several telecom companies, namely Safaricom, Airtel, Orange and Essar in Kenya. The owners of MMT can exchange cash for e-money at any "mobile money agent" locations. They can also send this money to anyone in the country with a text message, even if the recipient is not a registered mobile money holder and even if the phone operates on another network. Depositing funds for e-money is free, while an SMS costs about 30 Kenyan Shillings 
(40 cents). Withdrawals are charged at about 1-2 percent and the price is higher if the recipient is not a registered owner of MMT or uses a different cellular network than the sender. ${ }^{2}$

Our data have been drawn from the longitudinal Socio-Economic Survey (SES) ${ }^{3}$, conducted in the Kisumu Region, near Lake Victoria, of Kenya. The SES is compiled from quarterly visits to about 1600 households in 10 villages. The survey period in this paper is roughly from February 2013 to December 2016.

Table 1 provides descriptions of the variables. Table 2 provides the means and standard deviations of the variables of interest. Average Total Expenditure during a quarter is about 10,127.8 Kshs. ( \$101) with education and other expenditures constituting the largest expenditure categories. Other expenditures may include expenditures related to livestock and crop farming or recreation. The average healthcare expenditure for households during a quarter is $516.46(\sim 5)$.

We define healthcare use through three variables; Visits Made to a clinic, whether or not medication expenditure was incurred (Medication), and whether or not a consultation fee was paid (Consultation), all during the last quarter. Visits Made to a clinic indicates the number of visits to a formal healthcare facility but does not indicate if such a facility was used to buy medicines or for doctor consultation. In the region, one of the hospitals charges no consultation fee and the Visits Made variable in such a case may only capture opportunity cost of time and transportation costs. We also want to examine if users of $M M T$ are more likely to use this technology for medication expenditures or consultation expenditures or both.

\footnotetext{
${ }^{2}$ Registration only requires a National ID card or Passport. Detailed information regarding pricing for one of the cellular service is available at https://www.safaricom.co.ke/personal/m-pesa/getting-started/m-pesa-rates

${ }^{3}$ This survey was launched by Paul G. Allen School for Global Animal Health at Washington State University in collaboration with the Kenya Medical Research Institute and U.S. Centers for Disease Control and Prevention (known as the KEMRI/CDC Research and Public Health Collaboration) and the University of Washington with a goal to reduce poverty and hunger and improve health and education.
} 
Average adoption rates of $M M T$ over the survey period are shown in Figure 1. The user rate of $M M T$ remains around 60 percent at the household level in our sample during all time periods while the overall cell phone ownership remains around 70 percent. In our region and sample, the rate of penetration of this technology hasn't been increasing over time, whereas other studies of mobile money report an increasing trend in the adoption of this technology (Munyegera and Matsumoto 2016; Jack and Suri 2011, 2014). Barriers to use this technology include failed transactions, dissatisfaction over mobile carriers' customer service and cash shortages especially in rural areas (Morawczynski and Pickens 2009).

Shock is an indicator variable equal to 1 if any household member has been sick (could not go to work or go to school) in the past 3 months, 0 otherwise. In the sample, health shocks are the most dominant shocks compared to livestock health shocks and crop loss. On average, $42 \%$ of the households report illness incidence within the household in the preceding quarter. In some of the time periods, as high as $52 \%$ of households report illness, suggesting that risk due to disease is a prominent issue in these households. Figure 2 illustrates the proportion of households that experience the shock during each survey period.

Table 2 also reports the level of cash savings and the percentage of households that take a loan (formally or informally) during the survey period. $10 \%$ of the households report that they took a loan during the survey period. Only $44 \%$ of the population reported that they had positive cash savings, and mostly the savings were less than 5,000 Kshs. ( \$50). There were significant differences in the wealth of households. The wealth variable is constructed from farm and offfarm incomes, value of livestock and value of crop inventory. This component of wealth can also be thought of as savings, since livestock are often used as precautionary savings assets (McPeak 
2006). Other assets that could help in risk sharing like acres of land owned and ownership of a phone enter as independent variables in the analysis.

\section{Empirical Framework}

Our focus is to determine the impact of $M M T$ on consumption and healthcare use in the face of health shocks. Following Jack and Suri (2014), we employ the following difference-in-difference specification to test whether consumption and healthcare usage of users and non-users of MMT differs under health shocks:

$$
\begin{aligned}
\text { Expend }_{i v t} & =\alpha_{i}+\gamma \text { shock }_{i v t}+\beta \text { shock }_{i v t} * M M T_{i v t}+\lambda M M T_{i v t}+\mu X_{i v t}+\theta \text { shock }_{i v t} * X_{i v t} \\
& +\delta_{v t}+\epsilon_{i v t}
\end{aligned}
$$

where Expend $_{i v t}$ is (a) expenditures for different consumption categories, and (b) healthcare usage captured by visits to a clinic or expenditures on medication and consultation, in household $i$, village $v$, and time $t$. shock $k_{i v t}$ is a dummy variable equal to 1 if the household reported illness in the preceding quarter and 0 otherwise. $M M T_{i v t}$ is a dummy variable equal to 1 if any member of the household is a user of mobile money technology and 0 otherwise. $\alpha_{i}$ represents a household fixed effect that controls for unobserved time-invariant household characteristics. ${ }^{4}$ The inclusion of household fixed effects implies that only those that switch $M M T$ status over the quarters contribute to estimation of $\hat{\lambda}$. $\delta_{v t}$ are village by time dummy variables that control for time variant village-level heterogeneity. $X_{i v t}$ contains occupational dummy variables, a dummy for whether a household owns a mobile phone or not, travel time to the hospital/clinic, dummies for highest educational attainment of the household, total adult household members and children,

\footnotetext{
${ }^{4}$ Household and time fixed effects explain $36 \%$ of the variation in $M M T$ status. We examine the sensitivity of our results to removing household fixed effects in Appendix Tables 1 and 2. In general, our results are quite similar with and without these effects included in the model.
} 
total household wealth, household's savings level, and owned acres. This empirical strategy also closely emulates Gertler and Gruber (2002), Gertler, Levine and Moretti (2006, 2009) and Robinson and Yeh (2011).

There are two main concerns that may cause problems in the interpretation of $\beta$ in the above specification. First is the exogeneity of the health shock. The validity of our identification strategy rests on the assumption that health shocks are exogenous and are equally likely to affect users and non-users of $M M T$. If health shocks are correlated with unobservables that affect $M M T$ adoption, then $\beta$ may not capture the causal effect of $M M T$ use on risk sharing.

Following Jack and Suri (2014), we test the exogeneity of health shocks by examining if they are correlated with adoption of MMT and a number of household-level variables.

$$
\operatorname{shock}_{i v t}=\alpha_{i}+\eta M M T_{i v t}+\rho X_{i v t}+\delta_{v t}+e_{i v t}
$$

The results for this regression are reported in Table 3. A significant effect of $M M T$ on shock would cause concern about selection bias: it may indicate that individuals who experience health shocks are more likely to obtain $M M T$ or that both health shocks and $M M T$ adoption are correlated with the same unobservables (either positively or negatively). We cannot reject the null hypothesis of zero effect of $M M T$ on shock, alleviating this concern. Furthermore, we do not find evidence of strong correlations between shock and wealth and education variables, which suggests that shock is also uncorrelated with the unobserved error term (Pei, Pischke and Schwandt 2017). Predictably, health shocks are correlated with number of children and adult members of the household. However, MMT adoption is not correlated with these variables, therefore the correlation between health shock and household size does not appear to be problematic in our estimation. ${ }^{5}$

\footnotetext{
${ }^{5}$ MMT use might help households reduce the risk of future health shocks. We added past MMT use and its interaction with past health shock in equation (2) and found small and statistically insignificant effects.
} 
The second main concern regards the endogeneity of MMT: why do some households adopt MMT while others do not? Along these same lines, since $M M T$ is correlated with observables like education, owning a cell phone, and wealth, it may be the case that it is correlated with unobserved variables that affect our dependent variables (such as expenditures or healthcare visits) as well. This will only be a problem to the extent that any difference between MMT users and non-users varies by health shock status. We follow Jack and Suri's (2014) strategy of allowing the effects of all observables to vary by health shock status as well, limiting the potential for the interaction between MMT and the health shock to be partially due to unobservables.

To further examine our assumption that unobserved differences by MMT status do not vary by health shock status, we plot trends in health expenditures for MMT users and non-users two quarters before and after a health shock. Figure 3 maps the pre- and post-shock means of healthcare expenditures unadjusted for right-hand side variables. Figure 4 shows means that are adjusted for right-hand side variables. Figures 3 and 4 illustrate that while MMT users consistently spend more on healthcare than non-users, there is no noticeable differential trend prior to a health shock. Furthermore, the larger difference in expenditures for MMT users that occurs in the quarter of a shock disappears in the two periods following the shock. These findings support the parallel trends assumption of our difference-in-difference framework.

The differences in the extent of consumption smoothing between users and non-users of MMT may arise from their borrowing behavior. The ability to obtain a loan, especially from an informal channel, should respond more to shocks for MMT users as compared to non-users. To test for this mechanism of risk-sharing, we examine the impact of $M M T$ on loans with the following linear probability model. 


$$
\begin{gathered}
\operatorname{loan}_{i v t}=\alpha_{i}+\gamma \operatorname{shock}_{i v t}+\beta \text { shock }_{i v t} * M M T_{i v t}+\lambda M M T_{i v t}+\mu X_{i v t} \\
+ \text { shock }_{i v t} * X_{i v t}+\delta_{v t}+\epsilon_{i v t}
\end{gathered}
$$

where $\operatorname{loan}_{\text {ivt }}$ is a dummy variable equal to 1 if household acquired a loan (formally or informally) in the past quarter and 0 otherwise, while right-hand side variables are the same as in Equation (1). ${ }^{6}$

Furthermore, if $M M T$ users rely on loans for risk-sharing, then the quantity of in-kind transfers and gifts should be less responsive to shock for $M M T$ users (if in-kind transfers and cash loans via $M M T$ are substitutes). To test if $M M T$ substitutes for in-kind transfers, we examine the impact of $M M T$ on the quantity of maize received as a gift (Maize Gift) with the following linear model.

$$
\begin{gathered}
\text { MaizeGift }_{i v t}=\alpha_{i}+\gamma_{\text {shock }} \text { ivt }+\beta \text { shock }_{i v t} * M M T_{i v t}+\lambda M M T_{i v t}+\mu X_{i v t} \\
+\theta \text { shock }_{i v t} * X_{i v t}+\delta_{v t}+\epsilon_{i v t}
\end{gathered}
$$

Standard errors are clustered at the household level in all regressions to account for the serial and intra-household correlation in errors for all regression specifications.

\section{Results}

\section{Effect on Expenditures}

The results of the difference-in-difference regressions for per capita expenditures in different categories under a health shock are reported in Table $4 .{ }^{7}$ Column 1 shows that all households

\footnotetext{
${ }^{6}$ Our data does not specify whether the loan was acquired via a formal or an informal channel. Therefore, we are unable to estimate the extent to which MMT affects loans through formal or informal channels separately.

${ }^{7}$ Since the dependent variable is in natural logarithms in many of our regressions and our variables of interest are dummy variables, the transformation of multiplying estimators by 100 and interpreting them as percentage changes is erroneous (Halvorsen and Palmquist 1980; Garderen and Shah 2002). To calculate percentage changes, we use Kennedy's (1981) transformation of our coefficients in all semi-logarithmic regressions. Kennedy's Transformation: $\%$ change $=100\left(\exp \left\{\beta-\frac{1}{2} \operatorname{Var}(\beta)\right\}-1\right)$.
} 
experience a large jump in health expenditures during a shock. However, users of $M M T$ spend about $63 \%$ (p-value < 0.001) more per capita on healthcare than the non-users during a shock, or roughly one-half more than the increase for households without $M M T$. This is consistent with the idea that $M M T$ helps alleviate cash constraints during periods when households need medical attention.

Looking across the other columns of Table 4, it is apparent that health shocks have little effect on non-health expenditures (individually or all together) for both $M M T$ users and nonusers. ${ }^{8}$ This is in contrast to Jack and Suri (2014), who find that health shocks decrease the nonhealth consumption of those who do not have $M M T$ but that $M M T$ alleviates this consumption risk. It is worth noting that Jack and Suri (2014) focus on shocks experienced in the past six months while the recall period in our data is 3 months. Under a longer recall period, respondents may only remember very severe shocks and may under-report less severe illness events (Bound et al. 2001). This difference in severity of shocks may explain the difference in estimates in the two papers. Health shocks at the household level may also be predominantly focused on vulnerable members like children (and other non-earning members of the household) (Black, Morris and Bryce 2003; Hsu et al. 2015) and therefore have little effect on earnings. ${ }^{9}$

Our results are in line with the results presented by Genoni (2012), Islam and Maitra (2012), Townsend (1994), and Kochar (1995) who suggest that nonmedical and food expenditures may be well insured against household illness. Consumption smoothing in food may occur through storage, in-kind gifts within informal networks, and substitution between on-farm production and

\footnotetext{
${ }^{8}$ Robustness checks for per capita expenditure regressions are provided in the Table A1 of the Appendix. Results for health, total non-health and total expenditures are robust to the inclusion of fewer controls than in the models presented in Table 4.

${ }^{9}$ Our data does not provide information on the individual within the household affected by disease. Therefore, we are unable to look at disaggregated effects.
} 
market purchases rather than borrowing cash (Asfaw and Braun 2004; De Weerdt and Dercon 2006). Similarly, education expenditure can be easily forecasted as such expenses are usually incurred at the beginning of the school term, whereas health expenditures may be incurred as a surprise (Marsh et al. 2016; Bharadwaj et al. 2019).

Our findings that non-health expenditures are generally not affected by negative health shocks and that the effect of $M M T$ is concentrated in healthcare expenditures could be the result of different things. Households may be unable or unwilling to adjust other parts of their budget to pay for medications and healthcare services or it could be that such expenses are small enough that they are able to keep other forms of consumption relatively constant over the quarter. Nevertheless, if households are liquidity constrained in the short run when acute health shocks arise (Beegle, Dehejia and Gatti 2003; Dupas 2009; Cohen and Dupas 2010; Bharadwaj et al. 2019), MMT could help them overcome these constraints by availing their social networks for loans or gifts to pay for needed healthcare (Fafchamps and Lund 2003; Fafchamps and Gubert 2007; De Weerdt and Dercon 2006).

The last thing we note about Table 4 is that the $M M T$ dummy variable is positively and significantly related to per capita expenditures in most of the consumption categories, indicating that adoption of $M M T$ is perhaps correlated with unobserved changes in a household's financial situation or other variables that affect expenditures. This is a weakness of our approach, since if, under a health shock, health expenditures increased more for MMT users than non-users for other (unobserved) reasons. Though we cannot rule this possibility out entirely, we present results later in this section on the acquisition of loans during health shocks that are consistent with the notion that $M M T$ itself is responsible for this difference.

\section{Effect on Healthcare Use}


Table 5 provides estimates of the impact of MMT on Visits Made to a clinic/hospital (Column 1), Medication (Column 2) and Consultation (Column 3) in the presence of health shock. MMT users visit formal healthcare facility 0.48 times more or roughly two-third times more during a shock than the households without $M M T$. Similarly, users of $M M T$ are 16 percentage points more likely to purchase medication, i.e., an almost $50 \%$ increase in the likelihood of purchasing medication than non-users during health shocks. Furthermore, users of $M M T$ are 15 percentage points more likely to spend on doctor consultation fees during health shocks than the non-users. In other words, $M M T$ users are almost twice as likely as non-users to spend on consultation fees during a shock. All of these estimates are statistically significant at the $1 \%$ level (p-value < 0.001). Regressions without household fixed effects and fewer covariates are provided in Appendix (Table 2A). ${ }^{10}$

These results provide evidence on the role of $M M T$ in increasing healthcare utilization during periods of illness. Even though formal healthcare facilities are inadequate in developing countries (Das, Hammer, and Leonard 2008), pursuing formal healthcare can still significantly improve health outcomes through timely receipt of treatment and important medication like antimalarials and oral rehydrate salts (Adhvaryu and Nyshadham 2015). The Kisumu region is associated with high malarial incidence as well as respiratory and digestive problems (Thumbi et al. 2015) and timely medication like anti-malarials or oral-rehydrate salts can significantly improve symptoms for those affected.

Table 6 examines explicitly the role of $M M T$ in the likelihood of the household acquiring a loan. The Took Loan variable documents loans from formal as well as informal sources. Users of

${ }^{10} M M T$ may have an impact on some of the control variables like savings. Therefore, controlling for savings may cause ambiguities in the interpretation of the effect of $M M T$ on risk-sharing. However, results from specifications without covariates (Table 2A) do not significantly differ from the results presented in Table 5, indicating that $M M T$ has a small role to play in terms of changing savings of the households. 
$M M T$ are 13 percentage points more likely to acquire a loan in general and about 2 to 5

percentage points more likely to acquire a loan in the face of health shocks, compared to nonusers, depending on different specifications. This is suggestive of borrowing being the mechanism by which health expenditures rise during an adverse health shock, where borrowing is aided by $M M T .^{11}$

Lastly, we note that households can rely on in-kind transfers like gifts of maize and livestock for risk sharing (McPeak 2006). If borrowing via $M M T$ is indeed responsible for users spending more on healthcare during health shocks than non-users, then $M M T$ users may be able to rely less on in-kind transfers. Table 7 examines the quantity of maize received as a gift (Maize Gift) during health shocks. We find that there is an increase of 5 to 9 percent in the amount of maize received by non-user households during health shocks. However, the negative and offsetting coefficient on $S h o k^{*} M M T$ suggests that $M M T$ users do not experience this increase of in-kind transfers during negative health shocks. These results are consistent with the notion that cash transfers via MMT substitute for in-kind transfers during periods of (health) distress.

\section{Conclusion}

This paper examines the role of MMT on risk sharing in consumption and builds on the work of Jack and Suri (2014) by focusing on healthcare expenditures and use in the face of negative health shocks. To the extent that financial services are unavailable in rural areas of developing countries, MMT can fill a valuable role for the unbanked rural poor by providing access to cash transfers from one's social network.

\footnotetext{
${ }^{11}$ Our estimates of borrowing will be underestimated to the extent that remittances from kin are based on relationships of reciprocity and may not be counted as loans by households.
} 
We find that during times of illness, users of MMT spend $63 \%$ more per capita on health, are $50 \%$ more likely to buy medication, are almost two times more likely to pay consultation fees, and utilize more formal healthcare facilities than non-users of the technology. Previous studies related to MMT adoption illustrate that use of MMT is associated with increased borrowing and remittances. We also show that users of MMT acquire more loans and rely less on in-kind transfers during health shocks. These results imply that digital financial services like MMT can be used to overcome credit or liquidity constraints that hamper the ability of the households to use necessary healthcare.

Self-insurance against health shocks due to MMT is important in the short run but may have even more important longer-run consequences on household welfare and poverty if utilization of healthcare services decrease mortality and long-term illness. Furthermore, if MMT adoption allows households to better utilize geographically dispersed social networks, it may replace or alter traditional local-level risk sharing relationships and institutions, as suggested by our results related to maize transfers among households. Estimating overall welfare impacts, changes in risk-sharing institutions and long-run consequences of MMT are topics for future work. 


\section{References}

Adhvaryu, A., and Nyshadham, A. (2015). Return to treatment in the formal health care sector: Evidence from Tanzania. American Economic Journal: Economic Policy 7(3), 29-57.

Agesa, J. and Agesa, R.U. (1999). Gender differences in the incidence of rural to urban migration: Evidence from Kenya. The Journal of Development Studies, 35(6), pp.36-58.

Aker, J. C., Boumnijel, R., McClelland, A., \& Tierney, N. (2011). Zap it to me: The short-term impacts of a mobile cash transfer program. Center for Global Development Working Paper No. 268.

Asfaw, A., and Braun, J. V. (2004). Is consumption insured against illness? Evidence on vulnerability of households to health shocks in rural Ethiopia. Economic Development and Cultural Change, 53(1), 115-129.

Beegle, Kathleen \& Dehejia, Rajeev and Gatti, Roberta. (2003). Child Labor, Crop Shocks, and Credit Constraints. National Bureau of Economic Research, Inc, NBER Working Papers.

Bharadwaj, P., Jack ,W., and Suri, T. (2019). Fintech and household resilience to shocks:

Evidence from digital loans in Kenya. National Bureau of Economic Research, Inc, NBER Working Paper No. 25604.

Black, R.E., Morris, S.S. and Bryce, J. (2003). Where and why are 10 million children dying every year? The lancet, 361(9376), pp.2226-2234.

Blumenstock, J., Eagle, N and Fafchamps, M. (2011). Risk sharing over the mobile phone network: Evidence from Rwanda. Unpublished manuscript, University of CaliforniaBerkeley.

Bound, J., Brown, C., and Mathiowetz, N. (2001). Measurement error in survey data. In Handbook of econometrics (Vol. 5, pp. 3705-3843). Elsevier. 
Cochrane, J. H. (1991). A simple test of consumption insurance. Journal of political economy, 99(5), 957-976.

Cohen, J., and Dupas, P. (2010). Free distribution or cost-sharing? Evidence from a randomized malaria prevention experiment. The Quarterly Journal of Economics, 1-45.

Das, J., Hammer, J., and Leonard, K. (2008). The quality of medical advice in low-income countries. Journal of Economic Perspectives 22(2), 93-114

Dercon, S., and Krishnan, P. (2000). In sickness and in health: Risk sharing within households in rural Ethiopia. Journal of political Economy, 108(4), 688-727.

De Weerdt, J., and Dercon, S. (2006). Risk-sharing networks and insurance against illness. Journal of Development Economics, 81(2), 337-356.

Dupas, P. (2009). What matters (and what does not) in households' decision to invest in malaria prevention? American Economic Review, 99(2), 224-30.

Fafchamps, M., and Gubert, F. (2007). The formation of risk sharing networks. Journal of Development Economics, 83(2), 326-350.

Fafchamps, M., and Lund, S. (2003). Risk-sharing networks in rural Philippines. Journal of Development Economics 71(2), 261-287.

Garderen, K.J., and Shah, C. (2002). Exact interpretation of dummy variables in semilogarithmic equations. Econometrics Journal 5, 149-159.

Genoni, M.E. (2012). Health shocks and consumption smoothing: Evidence from Indonesia." Economic Development and Cultural Change 60(3): 475-506.

Gertler, P and Gruber, J. (2002). Insuring consumption against illness. American Economic Review 92(1), 51-76. 
Gertler, P., Levine, D.I., and Moretti, E. (2006). Is social capital the capital of the poor? The role of family and community in helping insure living standards against health shocks. CESifo Economic Studies 52(3), 455-99.

Gertler, P., Levine, D.I., and Moretti, E. (2009). Do microfinance programs help families insure consumption against illness? Health Economics 18(3), 257-73.

Halvorsen, R., and Palmquist, R. (1980). The interpretation of dummy variables in semilogarithmic equations. American Economic Review 70, 474-5.

Harris, B., Goudge, J., Ataguba, J. E., McIntyre, D., Nxumalo, N., Jikwana, S., \& Chersich, M. (2011). Inequities in access to health care in South Africa. Journal of Public Health Policy 32(1), S102-S123.

Hsu, C. L., Lee, Y. S., Chen, C. J., Lee, M. L., Yang, C. F., Soong, W. J., ... \& Wu, K. G. (2015). A population-based analysis of children with pneumonia among intensive care units in Taiwan. Journal of Microbiology, Immunology and Infection, 48(2), 153-159.

Islam, A., and Maitra, P. (2012). Health shocks and consumption smoothing in rural households: Does microcredit have a role to play? Journal of Development Economics 97(2), 232243.

Jack, W., and Suri, T. (2014). Risk sharing and transaction costs: Evidence from Kenya's mobile money revolution. American Economic Review 104(1), 183-223.

Jack, W. and Suri, T. (2011). Mobile money: The economics of M-PESA (No. w16721). National Bureau of Economic Research.

Jütting, J.P. (2004). Do community-based health insurance schemes improve poor people's access to health care? Evidence from rural Senegal. World Development 32(2), 273-288. 
Kennedy, P.E. (1981). Estimation with correctly interpreted dummy variables in semilogarithmic equations. American Economic Review 71, 801.

Kikulwe, E. M., Fischer, E., and Qaim, M. (2014). Mobile money, smallholder farmers, and household welfare in Kenya. PloS One 9(10), e109804.

Kochar, A. (1995). Explaining household vulnerability to idiosyncratic income shocks. American Economic Review 85(2), 159-164.

Jakiela, P., and Ozier, O. (2015). Does Africa need a rotten kin theorem? Experimental evidence from village economies. The Review of Economic Studies 83(1), 231-268.

Marsh, T., Yoder, J., Deboche, T., McElwain, T., and Palmer, G. (2016). Pastoralists' decisions on livestock vaccination translate into increased human capital and increased school attendance by girls. Science Advances 2(12), e1601410.

Mbiti, I.M. and Weil, D. (2011). Mobile Banking: The Impact of M-Pesa in Kenya. NBER Working Paper No. w17129

McPeak, J. (2006). Confronting the risk of asset loss: What role do livestock transfers in northern Kenya play? Journal of Development Economics 81(2), 415-437

Mobarak, A.M. and Rosenzweig, M.R., (2013). Informal risk sharing, index insurance, and risk taking in developing countries. American Economic Review, 103(3), pp.375-80.

Morawczynski, O., and Pickens, M. (2009). Poor people using mobile financial services: Observations on customer usage and impact from M-PESA. CGAP: Washington, D.C.

Munyegera, G.K., and Matsumoto, T. (2016). Mobile money, remittances, and household welfare: Panel evidence from rural Uganda. World Development 79, 127-137. 
Pei, Z., Pischke, J.S, and Schwandt, H. (2017). Poorly measured confounders are more useful on the left than on the right. NBER working paper number 23232, http://www.nber.org/papers/w23232

Riley, E. (2018). Mobile money and risk sharing against village shocks. Journal of Development Economics, 135, 43-58.

Robinson, J., and Yeh, E. (2011). Transactional Sex as a Response to Risk in Western Kenya. American Economic Journal: Applied Economics, 3 (1): 35-64.

Schultz, T.P., and Tansel, A. (1997). Wage and labor supply effects of illness in Côte d'Ivoire and Ghana: instrumental variable estimates for days disabled. Journal of Development Economics 53(2), 251-286

Suri, T. (2012). Estimating the extent of risk sharing between households. Unpublished Manuscript.

Suri, T. and Jack, W. (2016). The long-run poverty and gender impacts of mobile money. Science, 354(6317), 1288-1292.

Thumbi, S.M., Njenga, M.K., Marsh, T.L., Noh, S., Otiang, E., Munyua, P., Ochieng, L., Ogola, E., Yoder, J., Audi, A. and Montgomery, J.M. (2015). Linking human health and livestock health: A One-Health platform for integrated analysis of human health, livestock health, and economic welfare in livestock dependent communities. PLoS One 10(3): e0120761. doi:10.1371/journal.pone.0120761

Townsend, R.M. (1994). Risk and insurance in village India. Econometrica, 62 (3), pp 593 - 591 Townsend, R. M. (1995). Consumption insurance: An evaluation of risk-bearing systems in lowincome economies. Journal of Economic perspectives, 9(3), 83-102. 


\section{Figures}

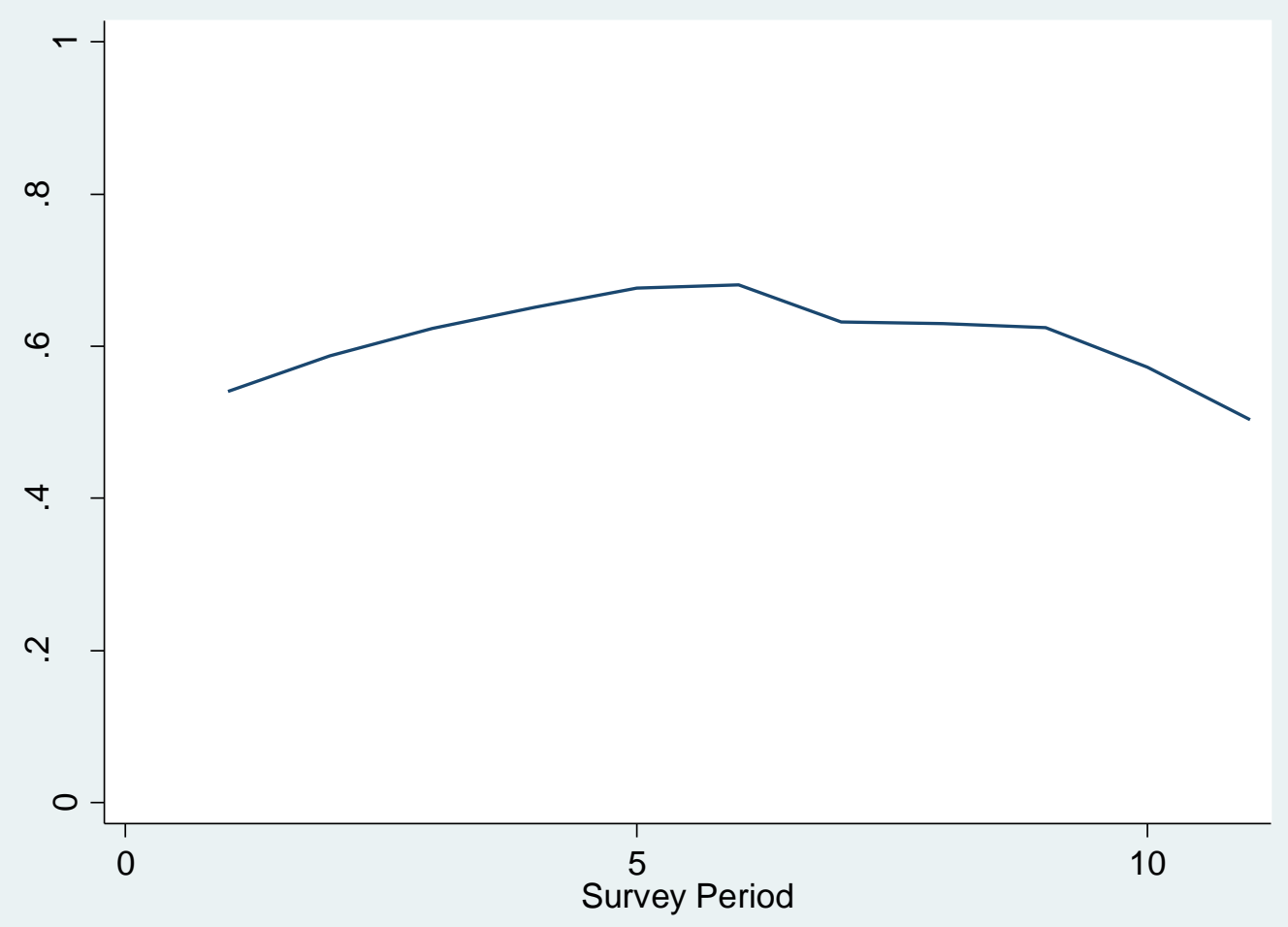

Figure 1: MMT penetration over time 


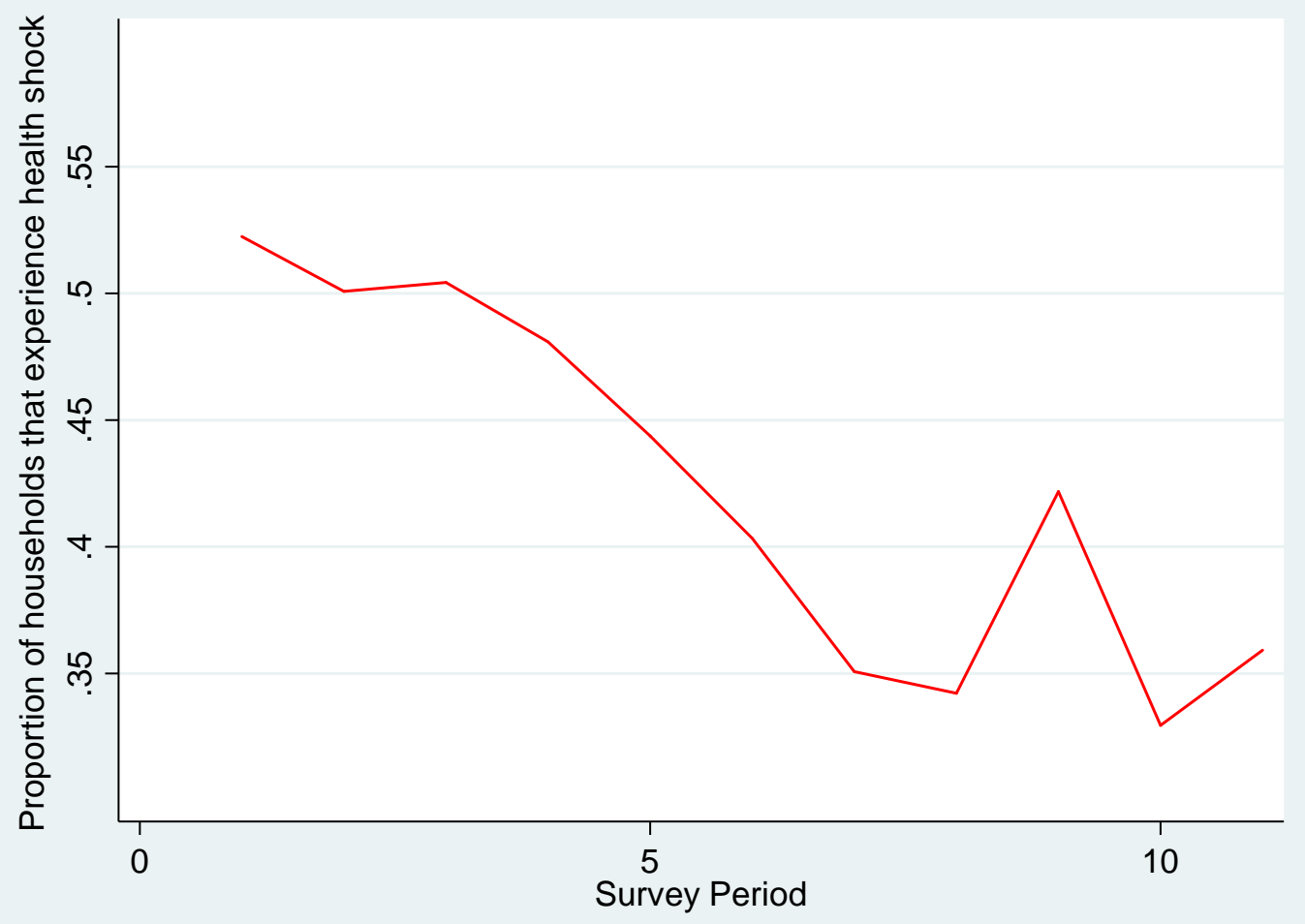

Figure 2: Proportion of households that experience a health shock in each time period 


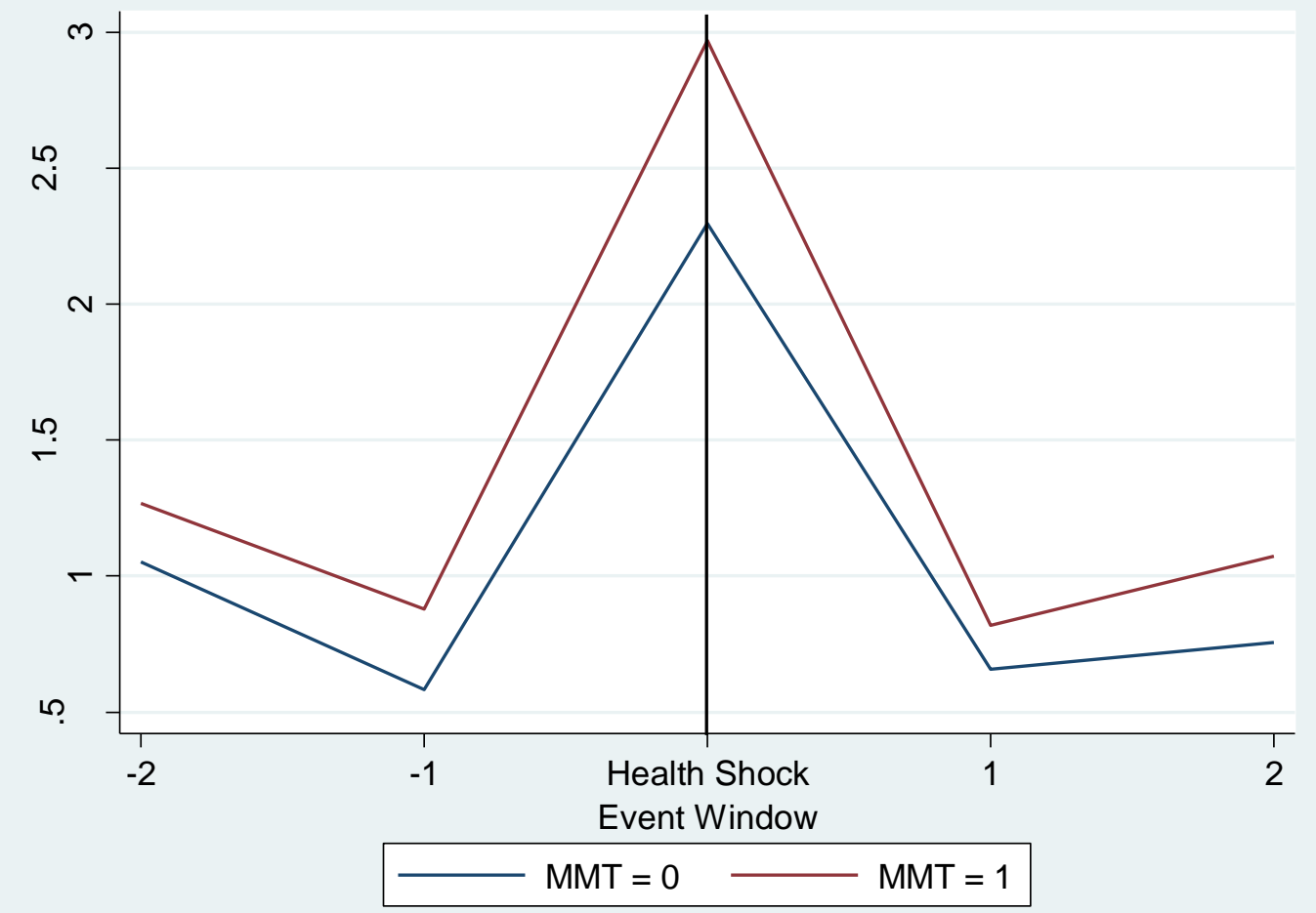

Figure 3: Mean (unadjusted for RHS variables) healthcare expenditures two quarters before and after a health shock 


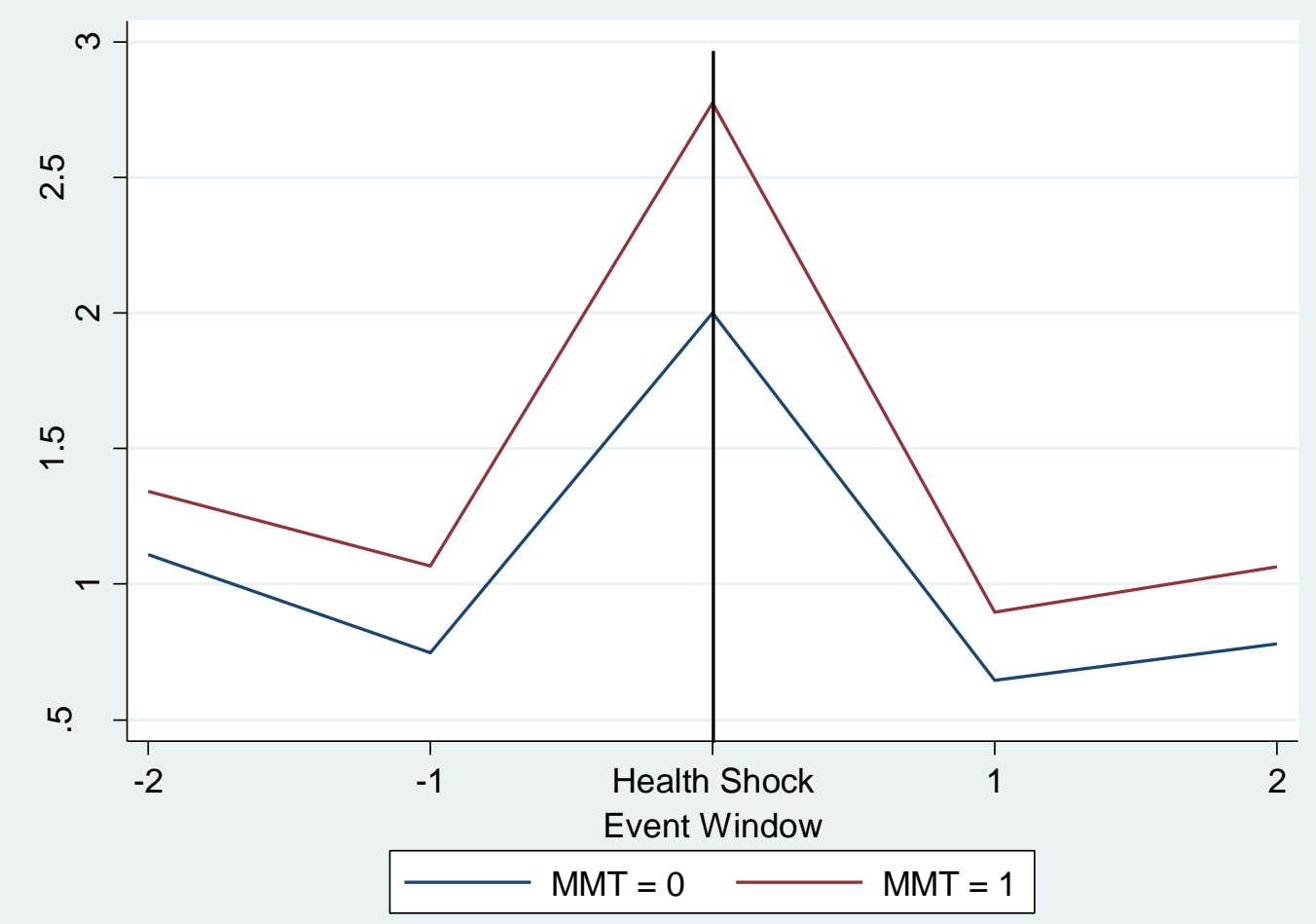

Figure 4: Mean (adjusted for RHS variables) healthcare expenditures two quarters before and after a health shock 


\section{Tables}

Table 1: Data Description

\begin{tabular}{|c|c|}
\hline Variable & Description \\
\hline$M M T$ & $\begin{array}{l}\text { Indicator variable }=1 \text { if any member of the household owns a } \\
\text { mobile money savings and transfer }(\mathrm{MMT}) \text { account, } 0 \\
\text { otherwise. }\end{array}$ \\
\hline Shock & $\begin{array}{l}\text { Indicator variable }=1 \text { if any household member has been sick } \\
\text { (could not go to work or go to school) in the past } 3 \text { months, } 0 \\
\text { otherwise. }\end{array}$ \\
\hline Visits Made & Number of visits made to a hospital/clinic in the past 3 months. \\
\hline Medication & $\begin{array}{l}\text { Indicator variable }=1 \text { if the household spent on medicines in the } \\
\text { past } 3 \text { months, } 0 \text { otherwise. }\end{array}$ \\
\hline Consultation & $\begin{array}{l}\text { Indicator variable }=1 \text { if the household spent on consultation } \\
\text { (doctor or traditional healer) in the past } 3 \text { months, } 0 \text { otherwise. }\end{array}$ \\
\hline Education Expenditure & $\begin{array}{l}\text { The natural log of the total per capita expenditure on education } \\
\text { by the household in the last } 3 \text { months. }\end{array}$ \\
\hline Healthcare Expenditure & $\begin{array}{l}\text { The natural log of the total per capita expenditure on health care } \\
\text { by the household in the last } 3 \text { months. }\end{array}$ \\
\hline Clothing Expenditure & $\begin{array}{l}\text { The natural log of the total per capita expenditure on clothing by } \\
\text { the household in the last } 3 \text { months. }\end{array}$ \\
\hline Food Expenditure & $\begin{array}{l}\text { The natural log of the total per capita expenditure on food by the } \\
\text { household in the last } 3 \text { months. }\end{array}$ \\
\hline Other Expenditure & $\begin{array}{l}\text { The natural log of total per capita expenditure on 'other' things } \\
\text { - not captured by categories above by the household in the last } 3 \\
\text { months. }\end{array}$ \\
\hline Total Expenditure & $\begin{array}{l}\text { The natural log of the total per capita expenditure by the } \\
\text { household in the last } 3 \text { months. }\end{array}$ \\
\hline Children & Household members of age less than or equal to 10. \\
\hline Adult HH members & Household members of age greater than 10. \\
\hline College Education & $\begin{array}{l}\text { Indicator variable }=1 \text { if highest education attainment of the } \\
\text { household is college education, } 0 \text { otherwise. }\end{array}$ \\
\hline Secondary Education & $\begin{array}{l}\text { Indicator variable }=1 \text { if highest education attainment of the } \\
\text { household is secondary education, } 0 \text { otherwise. }\end{array}$ \\
\hline Primary Education & $\begin{array}{l}\text { Indicator variable }=1 \text { if highest education attainment of the } \\
\text { household is primary education, } 0 \text { otherwise. }\end{array}$ \\
\hline Savings $<\$ 70$ & $\begin{array}{l}\text { Indicator variable }=1 \text { if households cash savings are }<\$ 70,0 \\
\text { otherwise. }\end{array}$ \\
\hline$\$ 70<$ Savings $<\$ 175$ & $\begin{array}{l}\text { Indicator variable }=1 \text { if households cash savings are between } \\
\$ 70 \text { and } \$ 175,0 \text { otherwise. }\end{array}$ \\
\hline Savings $>\$ 175$ & $\begin{array}{l}\text { Indicator variable }=1 \text {, if household cash savings are greater than } \\
\$ 175,0 \text { otherwise. }\end{array}$ \\
\hline Took Loan & $\begin{array}{l}\text { Indicator variable }=1 \text { if household received a loan (formally or } \\
\text { informally) in the past } 3 \text { months, } 0 \text { otherwise. }\end{array}$ \\
\hline
\end{tabular}




\begin{tabular}{|c|c|}
\hline Maize Gift & $\begin{array}{l}\text { Natural log of kilograms of maize received as a gift in the past } 3 \\
\text { months. }\end{array}$ \\
\hline Cell Phone Ownership & $\begin{array}{l}\text { Indicator variable }=1 \text {, if household owns a mobile phone, } 0 \\
\text { otherwise. }\end{array}$ \\
\hline Owned Acres & Acres of land owned by the household \\
\hline Wealth & $\begin{array}{l}\text { Income from crops, livestock and off-farm activities plus the } \\
\text { market value of the livestock and crop inventories. }\end{array}$ \\
\hline Farmer & $\begin{array}{l}\text { Indicator variable }=1 \text { if household head's primary occupation is } \\
\text { farming, } 0 \text { otherwise. }\end{array}$ \\
\hline Self Employed & $\begin{array}{l}\text { Indicator variable }=1 \text { if household head's primary occupation is } \\
\text { off-farm self-employed, } 0 \text { otherwise }\end{array}$ \\
\hline Household Help & $\begin{array}{l}\text { Indicator variable }=1 \text { if household head's primary occupation is } \\
\text { household help, } 0 \text { otherwise }\end{array}$ \\
\hline
\end{tabular}


Table 2: Summary Statistics

\begin{tabular}{|c|c|c|}
\hline & Mean & SD \\
\hline Food Expenditure (Kshs) & 778.9 & 583.7 \\
\hline Healthcare Expenditure (Kshs) & 516.46 & $3,515.8$ \\
\hline Education Expenditure (Kshs) & $3,907.01$ & $11,563.31$ \\
\hline Clothing Expenditure (Kshs) & 464.64 & $1,174.9$ \\
\hline Other Expenditure (Kshs) & $3,726.87$ & $5,252.12$ \\
\hline Total Expenditure & $10,127.8$ & $74,223.34$ \\
\hline Visits Made & 1.06 & 1.70 \\
\hline Consultation (percent) & 0.087 & 0.28 \\
\hline Medication (percent) & 0.30 & 0.45 \\
\hline$M M T$ (percent) & 0.61 & 0.48 \\
\hline College Education (percent) & 0.05 & 0.23 \\
\hline Primary Education (percent) & 0.45 & 0.49 \\
\hline Secondary Education (percent) & 0.29 & 0.45 \\
\hline Shock (percent) & 0.42 & 0.49 \\
\hline Wealth (Kshs.) & 84,921 & 77,183 \\
\hline Adult HH Members & 4.45 & 2.36 \\
\hline Children < Age 10 & 1.62 & 1.81 \\
\hline Cell Phone Ownership (percent) & 0.72 & 0.47 \\
\hline Maize Gift $(K g)$ & 1.44 & 9.4 \\
\hline Took Loan (Percent) & 0.11 & 0.31 \\
\hline \multirow{2}{*}{\multicolumn{3}{|c|}{$\begin{array}{l}\text { Household Head Occupation } \\
\text { Dummies (percent) }\end{array}$}} \\
\hline & & \\
\hline Farmer & 0.43 & 0.49 \\
\hline Self Employed & 0.14 & 0.34 \\
\hline Salaried & 0.03 & 0.19 \\
\hline Other & 0.08 & 0.27 \\
\hline Household Help & 0.32 & 0.43 \\
\hline \multicolumn{3}{|l|}{ Financial Instruments } \\
\hline No Savings (percent) & 0.56 & 0.48 \\
\hline Savings $<\$ 70$ (percent) & 0.43 & 0.49 \\
\hline$\$ 70<$ Savings $<\$ 175$ & 0.005 & 0.07 \\
\hline Savings $>\$ 175$ & 0.003 & 0.05 \\
\hline Took Loan (percent) & 0.106 & 0.31 \\
\hline
\end{tabular}

Data are compiled from quarterly visits to about 1600 households in 10 villages in Kisumu Region, near Lake Victoria, of Kenya. The survey period was roughly from February 2013 to December 2016.

Number of Observations $\approx 15,000$ 


\section{Table 3: Correlates of Health Shock - Linear Probability Model}

\begin{tabular}{lr}
\hline & Health Shock \\
\hline MMT & 0.09 \\
Wealth & $(0.08)$ \\
& 0.0004 \\
Savings & $(0.0003)$ \\
College Education & -0.092 \\
& $(0.063)$ \\
Primary Education & 0.065 \\
& $(0.047)$ \\
Secondary Education & 0.036 \\
& $(0.035)$ \\
Children & 0.045 \\
Total Household Members & $(0.042)$ \\
Occupation - House help & $0.011 * *$ \\
Occupation - Self Employed & $(0.005)$ \\
Occupation - Salaried & $0.017 * * *$ \\
Cell Phone Ownership & $(0.006)$ \\
Owned Acres & 0.061 \\
& $(0.081)$ \\
& -0.021 \\
& $(0.033)$ \\
& -0.102 \\
& $(0.083)$ \\
& -0.037 \\
& $(0.029)$ \\
& -0.0003 \\
& $(0.0002)$ \\
& 0.04 \\
& 14,609 \\
\hline
\end{tabular}

$* * *, * *, *$ indicate significance at 1,5 and $10 \%$ respectively.

Standard errors are clustered at the household level.

Dependent variable, Health Shock, is an indicator variable $=1$ if any household member has been sick (could not go to work or go to school) in the past 3 months and 0 otherwise. 
Table 4: The Effect of Mobile Money on Expenditure (in Logs) during a Health Shock

\begin{tabular}{|c|c|c|c|c|c|c|c|}
\hline & $\begin{array}{r}\text { Health } \\
\text { Expenditure }\end{array}$ & $\begin{array}{l}\text { Education } \\
\text { Expenditure }\end{array}$ & $\begin{array}{r}\text { Food } \\
\text { Expenditure }\end{array}$ & $\begin{array}{r}\text { Clothing } \\
\text { Expenditure }\end{array}$ & $\begin{array}{r}\text { Other } \\
\text { Expenditure }\end{array}$ & $\begin{array}{l}\text { Non-Health } \\
\text { Expenditure }\end{array}$ & $\begin{array}{r}\text { Total } \\
\text { Expenditure }\end{array}$ \\
\hline Shock $^{a}$ & $\begin{array}{r}1.37 * * * \\
(0.21)\end{array}$ & $\begin{array}{r}0.081 \\
(0.122)\end{array}$ & $\begin{array}{r}-0.008 \\
(0.11)\end{array}$ & $\begin{array}{r}0.083 \\
(0.107)\end{array}$ & $\begin{array}{c}0.128 \\
(0.10)\end{array}$ & $\begin{array}{r}0.039 \\
(0.118)\end{array}$ & $\begin{array}{r}0.44 * * * \\
(0.132)\end{array}$ \\
\hline$M M T$ & $\begin{array}{r}0.28^{* *} \\
(0.09)\end{array}$ & $\begin{array}{r}1.02 * * * \\
(0.12)\end{array}$ & $\begin{array}{r}0.16 \\
(0.35)\end{array}$ & $\begin{array}{r}1.01 * * * \\
(0.116)\end{array}$ & $\begin{array}{r}0.11^{*} \\
(0.065)\end{array}$ & $\begin{array}{r}0.501 * * * * \\
(0.055)\end{array}$ & $\begin{array}{r}0.495^{* * * *} \\
(0.055)\end{array}$ \\
\hline Shock*MMT & $\begin{array}{r}0.63 * * * \\
(0.148)\end{array}$ & $\begin{array}{l}0.012 \\
(0.18)\end{array}$ & $\begin{array}{r}-0.058 \\
(0.047)\end{array}$ & $\begin{array}{r}0.276 \\
(0.173)\end{array}$ & $\begin{array}{r}0.02 \\
(0.10)\end{array}$ & $\begin{array}{r}0.026 \\
(0.078)\end{array}$ & $\begin{array}{r}0.071 \\
(0.079)\end{array}$ \\
\hline No. of Observations & 14,604 & 14,603 & 14,608 & 14,607 & 14,601 & 14,602 & 14,599 \\
\hline R-Square & 0.38 & 0.53 & 0.52 & 0.33 & 0.51 & 0.54 & 0.53 \\
\hline Time by Village Effects & Yes & Yes & Yes & Yes & Yes & Yes & Yes \\
\hline Household Fixed Effects & Yes & Yes & Yes & Yes & Yes & Yes & Yes \\
\hline Controls & Yes & Yes & Yes & Yes & Yes & Yes & Yes \\
\hline Controls*Shock & Yes & Yes & Yes & Yes & Yes & Yes & Yes \\
\hline
\end{tabular}

${ }^{a}$ Marginal effect estimated at mean of the controls.

$* * *, * *, *$ indicate significance at 1,5 and $10 \%$ respectively.

Standard errors are clustered at the household level.

Dependent variables constitute different categories of expenditures (in logs). Control variables include occupational dummy variables, a dummy for whether a household owns a mobile phone or not, dummies for highest educational attainment of the household, total adult household members and children, total household wealth, household's savings level, and owned acres. 
Table 5: The Effect of Mobile Money on Visits Made, Medication and Consultation

\begin{tabular}{lrrr}
\hline & Visits Made & Medication & Consultation \\
\hline Shock & & & \\
MMT & $0.67^{* * *}$ & $0.35^{* * *}$ & $0.09^{* * *}$ \\
& $(0.163)$ & $(0.036)$ & $(0.02)$ \\
Shock*MMT & $0.26^{* * *}$ & $0.11^{* * *}$ & 0.0034 \\
& $(0.068)$ & $(0.02)$ & $(0.011)$ \\
No. of Observations & $0.484^{* * *}$ & $0.164^{* * *}$ & $0.15^{* * *}$ \\
R-Square & $(0.16)$ & $(0.031)$ & $(0.02)$ \\
\hline Time by Village Effects & & & \\
Household Fixed Effects & 14,609 & 14,603 & 14,603 \\
Controls & 0.32 & 0.32 & 0.22 \\
Controls*Shocks & Yes & Yes & Yes \\
\hline
\end{tabular}

${ }^{a}$ Marginal effect estimated at mean of controls.

$* * *, * *, *$ indicate significance at 1,5 and $10 \%$ respectively.

Standard errors are clustered at the household level.

Dependent variables are Visits Made, Medication and Consultation. Control variables include occupational dummy variables, a dummy for whether a household owns a mobile phone or not, travel time to the hospital/clinic, dummies for highest educational attainment of the household, total adult household members and children, total household wealth, household's savings level, and owned acres. 
Table 6: The Effect of Mobile Money on Acquisition of Loans - Linear Probability Model

\begin{tabular}{lrrrr}
\hline $\begin{array}{l}\text { Dependent Variable } \\
\text { Took Loan (Yes/No) }\end{array}$ & \multicolumn{1}{c}{$(1)$} & \multicolumn{1}{c}{$(2)$} & \multicolumn{1}{c}{$(3)$} & \\
\hline Shock & $0.014^{* * *}$ & $0.0079^{*}$ & $0.0082^{*}$ & 0.0069 \\
& $(0.003)$ & $(0.004)$ & $(0.004)$ & $(0.011)$ \\
MMT & $0.145^{* * *}$ & $0.116^{* * *}$ & $0.137^{* * *}$ & $0.175^{* * *}$ \\
& $(0.006)$ & $(0.006)$ & $(0.013)$ & $(0.017)$ \\
Shock*MMT & $0.016^{*}$ & $0.018^{* *}$ & $0.022^{* *}$ & $0.056^{* *}$ \\
& $(0.008)$ & $(0.008)$ & $(0.008)$ & $(0.022)$ \\
No. of Observations & 15,392 & 15,392 & 14,609 & 14,609 \\
R-Square & 0.07 & 0.29 & 0.30 & 0.30 \\
\hline Time by Village Effects & Yes & Yes & Yes & Yes \\
Household Fixed Effects & No & Yes & Yes & Yes \\
Controls & No & No & Yes & Yes \\
Controls*Shocks & No & No & No & Yes \\
\hline
\end{tabular}

$* * *, * *, *$ indicate significance at 1,5 and $10 \%$ respectively.

Standard errors are clustered at the household level.

Dependent variable, Took Loan, is an indicator variable $=1$ if household received a loan (formally or informally) in the past 3 months, 0 otherwise. Control variables include occupational dummy variables, a dummy for whether a household owns a mobile phone or not, dummies for highest educational attainment of the household, total adult household members and children, total household wealth, household's savings level, and owned acres. 


\section{Table 7: The Effect of Mobile Money on Log of Maize Gift Received}

\begin{tabular}{lrrrr}
\hline $\begin{array}{l}\text { Dependent Variable } \\
\text { Maize Gift }\end{array}$ & \multicolumn{1}{c}{$(1)$} & \multicolumn{1}{c}{$(2)$} & \multicolumn{1}{c}{$(3)$} & \multicolumn{1}{c}{$(4)$} \\
\hline Shock & $0.07^{* * *}$ & $0.05^{* *}$ & $0.06^{* * *}$ & $0.09^{\mathrm{a}}$ \\
& $(0.019)$ & $(0.021)$ & $(0.021)$ & $(0.086)$ \\
MMT & $0.03^{*}$ & $0.09^{* * *}$ & $0.07^{* * *}$ & 0.045 \\
& $(0.016)$ & $(0.017)$ & $(0.024)$ & $(0.028)$ \\
Shock*MMT & $-0.085^{* * *}$ & $-0.075^{* * *}$ & $-0.09^{* * *}$ & -0.042 \\
& $(0.024)$ & $(0.026)$ & $(0.027)$ & $(0.044)$ \\
No. of Observations & 13,955 & 13,955 & 13,482 & 13,482 \\
R-Square & 0.02 & 0.18 & 0.19 & 0.20 \\
\hline Time by Village Effects & Yes & Yes & Yes & Yes \\
Household Fixed Effects & No & Yes & Yes & Yes \\
Controls & No & No & Yes & Yes \\
Controls*Shocks & No & No & No & Yes \\
\hline
\end{tabular}

$* * *, * *, *$ indicate significance at 1,5 and $10 \%$ respectively.

Standard errors are clustered at the household level.

${ }^{a}$ Marginal effects at mean of controls.

Dependent variable, Maize Gift, is the natural log of kilograms of maize received as gift in the past 3 months. Control variables include occupational dummy variables, a dummy for whether a household owns a mobile phone or not, dummies for highest educational attainment of the household, total adult household members and children, total household wealth, household's savings level, and owned acres. 


\section{Appendix}

Table A1: The Effect of Mobile Money on Education, Health and Food Expenditures (in Logs) during a Human Illness Shock - Robustness Checks

\begin{tabular}{|c|c|c|c|c|c|c|c|c|c|}
\hline & $\begin{array}{l}\text { Health } \\
\text { Expenditure }\end{array}$ & $\begin{array}{l}\text { Health } \\
\text { Expenditure }\end{array}$ & $\begin{array}{l}\text { Health } \\
\text { Expenditure }\end{array}$ & $\begin{array}{l}\text { Non-Health } \\
\text { Expenditure }\end{array}$ & $\begin{array}{l}\text { Non-Health } \\
\text { Expenditure }\end{array}$ & $\begin{array}{l}\text { Non-Health } \\
\text { Expenditure }\end{array}$ & $\begin{array}{l}\text { Total } \\
\text { Expenditure }\end{array}$ & $\begin{array}{l}\text { Total } \\
\text { Expenditure }\end{array}$ & $\begin{array}{l}\text { Total } \\
\text { Expenditure }\end{array}$ \\
\hline Shock & $\begin{array}{r}1.41 * * * \\
(0.068)\end{array}$ & $\begin{array}{r}1.21 * * * \\
(0.066)\end{array}$ & $\begin{array}{r}1.35 * * * \\
(0.067)\end{array}$ & $\begin{array}{r}-0.027 \\
(0.042)\end{array}$ & $\begin{array}{r}0.017 \\
(0.035)\end{array}$ & $\begin{array}{r}0.039 \\
(0.035)\end{array}$ & $\begin{array}{r}0.185 * * * \\
(0.04)\end{array}$ & $\begin{array}{r}0.19 * * * \\
(0.036)\end{array}$ & $\begin{array}{r}0.22 * * * \\
(0.037)\end{array}$ \\
\hline$M M T$ & $\begin{array}{r}0.28 * * * \\
(0.041)\end{array}$ & $\begin{array}{r}0.301 * * * \\
(0.047)\end{array}$ & $\begin{array}{r}0.291 * * * \\
(0.081)\end{array}$ & $\begin{array}{r}0.91 * * * \\
(0.038)\end{array}$ & $\begin{array}{r}0.576 * * * \\
(0.029)\end{array}$ & $\begin{array}{r}0.536 * * * \\
(0.044)\end{array}$ & $\begin{array}{r}0.89 * * * \\
(0.038)\end{array}$ & $\begin{array}{r}0.60 * * * \\
(0.03)\end{array}$ & $\begin{array}{r}0.55 * * * \\
(0.044)\end{array}$ \\
\hline Shock*MMT & $\begin{array}{r}0.51 * * * \\
(0.082)\end{array}$ & $\begin{array}{r}0.479 * * * \\
(0.082)\end{array}$ & $\begin{array}{r}0.527 * * * \\
(0.084)\end{array}$ & $\begin{array}{r}-0.012 \\
(0.05)\end{array}$ & $\begin{array}{c}-0.029 \\
(0.049)\end{array}$ & $\begin{array}{r}-0.032 \\
(0.041)\end{array}$ & $\begin{array}{r}-0.05 \\
(0.05)\end{array}$ & $\begin{array}{r}-0.052 \\
(0.04)\end{array}$ & $\begin{array}{r}-0.052 \\
(0.04)\end{array}$ \\
\hline No. of Observations & 15,377 & 15,377 & 14,604 & 15,374 & 15,374 & 14,602 & 15,371 & 15,371 & 14,599 \\
\hline R-Square & 0.14 & 0.36 & 0.37 & 0.12 & 0.51 & 0.54 & 0.12 & 0.49 & 0.53 \\
\hline Time by Village Effects & Yes & Yes & Yes & Yes & Yes & Yes & Yes & Yes & Yes \\
\hline Household Fixed Effects & No & Yes & Yes & No & Yes & Yes & No & Yes & Yes \\
\hline Controls & No & No & Yes & No & No & Yes & No & No & Yes \\
\hline Controls*Shock & No & No & No & No & No & No & No & No & No \\
\hline
\end{tabular}

$* * *, * *, *$ indicate significance at 1,5 and $10 \%$ respectively.

Standard errors are clustered at the household level.

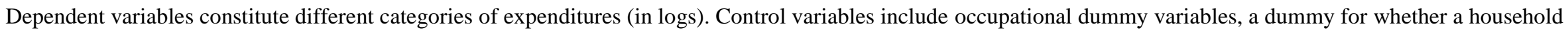
owns a mobile phone or not, dummies for highest educational attainment of the household, total adult household members and children, total household wealth,

household's savings level, and owned acres. 
Table A2: The Effect of Mobile Money on Visits Made, Medication and Consultation - Robustness Checks

\begin{tabular}{|c|c|c|c|c|c|c|c|c|c|}
\hline & $\begin{array}{l}\text { Visits } \\
\text { Made }\end{array}$ & $\begin{array}{l}\text { Visits } \\
\text { Made }\end{array}$ & $\begin{array}{l}\text { Visits } \\
\text { Made }\end{array}$ & Medication & Medication & Medication & Consultation & Consultation & Consultation \\
\hline Shock & $\begin{array}{r}1.19 * * * \\
(0.073)\end{array}$ & $\begin{array}{r}1.10 * * * \\
(0.084)\end{array}$ & $\begin{array}{r}0.958 * * * \\
(0.081)\end{array}$ & $\begin{array}{r}0.214 * * * * \\
(0.011)\end{array}$ & $\begin{array}{r}0.192^{* * * *} \\
(0.012)\end{array}$ & $\begin{array}{r}0.189^{* * * *} \\
(0.013)\end{array}$ & $\begin{array}{r}0.082^{* * * *} \\
(0.007)\end{array}$ & $\begin{array}{r}0.07 * * * \\
(0.007)\end{array}$ & $\begin{array}{r}0.074 * * * \\
(0.008)\end{array}$ \\
\hline$M M T$ & $\begin{array}{r}0.271 * * * \\
(0.036)\end{array}$ & $\begin{array}{r}0.294 * * * \\
(0.045)\end{array}$ & $\begin{array}{r}0.21 * * * \\
(0.076)\end{array}$ & $\begin{array}{r}0.103 * * * \\
(0.008)\end{array}$ & $\begin{array}{r}0.12 * * * * \\
(0.009)\end{array}$ & $\begin{array}{r}0.113 * * * * \\
(0.017)\end{array}$ & $\begin{array}{r}0.014 * * * \\
(0.003)\end{array}$ & $\begin{array}{r}0.016^{* * * *} \\
(0.01)\end{array}$ & $\begin{array}{r}0.04 * * * \\
(0.01)\end{array}$ \\
\hline Shock*MMT & $\begin{array}{r}0.633 * * * \\
(0.084)\end{array}$ & $\begin{array}{r}0.556 * * * \\
(0.097)\end{array}$ & $\begin{array}{r}0.596 * * * \\
(0.096)\end{array}$ & $\begin{array}{r}0.144 * * * \\
(0.015)\end{array}$ & $\begin{array}{r}0.129 * * * \\
(0.016)\end{array}$ & $\begin{array}{r}0.142 * * * \\
(0.016)\end{array}$ & $\begin{array}{r}0.084 * * * \\
(0.01)\end{array}$ & $\begin{array}{r}0.075 * * * \\
(0.005)\end{array}$ & $\begin{array}{r}0.076 * * * \\
(0.01)\end{array}$ \\
\hline No. of Obs. & 15,392 & 15,392 & 14,609 & 15,385 & 15,385 & 14,603 & 15,385 & 15,385 & 14,603 \\
\hline R-Square & 0.11 & 0.29 & 0.31 & 0.13 & 0.30 & 0.31 & 0.08 & 0.21 & 0.22 \\
\hline Time by Village Effects & Yes & Yes & Yes & Yes & Yes & Yes & Yes & Yes & Yes \\
\hline Household Fixed Effects & No & Yes & Yes & No & Yes & Yes & No & Yes & Yes \\
\hline Controls & No & No & Yes & No & No & Yes & No & No & Yes \\
\hline Controls*Shock & No & No & No & No & No & No & No & No & No \\
\hline
\end{tabular}

$* * *, * *, *$ indicate significance at 1,5 and $10 \%$ respectively.

Standard errors are clustered at the household level.

Control variables include occupational dummy variables, a dummy for whether a household owns a mobile phone or not, travel time to the hospital/clinic, dummies for highest educational attainment of the household, total adult household members and children, total household wealth, household's savings level, and owned acres. 